mercial enterprises and a corpus of economic terms that could be used by all countries. It also discussed the difficult topic of the measurement of forest work productivity with Section 32 (Operational Efficiency) the other main topics of which, under the chairmanship of Prof. V. Sundberg of Stockholm, were the effects of noise and vibration on the forest worker and the establishment of university courses in operational efficiency. Section 41 (Mechanical Conversion), led by Prof. J. Campredon of Paris, discussed many aspects of this subject and decided to enlarge its field of study so as to embrace all forest products (this to be the new name of the Section), with three initial working groups for wood quality, behaviour of wood exposed to fire, and sawing and machining.

Finally, on the initiative of Austria and Germany, the Union decided to create a new section, Section 11, on the History of Forestry, with Prof. von Mantel (West Gormany) as leader.

The Bibliographical Section, which is actually a joint committee of the Food and Agriculture Organization and Union representatives, met as usual several days before the Congress, under the chairmanship of Prof. E. Saari of Helsinki. It was concerned mainly with the prosecution of two long-term projects-further accurate translations of the classification now widely accepted in the world of forestry science (The Oxford System of Decimal Classification for Forestry, of which English, French, German and Spanish authorized editions have already appeared) and speeding up the production on cards of a basic forest terminology in the English language, as an essential preliminary to the multilingual terminology project, sponsored jointly by the Food and Agriculture Organization and the Union.
Prof. J. Speer (West Germany) was elected to be president in succession to Mr. Macdonald, whose term of office expires at the end of the year. Dr. V. L. Harper (United States) was elected vice-president. Elections to the Permanent Committee (previous members in italics) were: Prof. N. Anutschin (U.S.S.R.), Prof. T. Bunusevac (Yugoslavia), Prof. J. Campredon (France), Dr. E. Holmsgaard (Denmark), Prof. A. Horky (Austria), Prof. M. Kreutzinger (Poland), Prof. A. de Phillipis (Italy), Dr. D. R. Redmond (Canada), Dr. H. Shirley (United States), and Dr. Saito (Japan), leaving two places to be filled by representatives from India and Latin America, not yet designated.

The International Council met on the concluding day, and agreed to the revised statutes which take into account recent decisions of and developments in the Union, the major changes boing to strengthen the position and powers of the enlarged Permanent Committee which is its executive body between Congresses. A new class of member-associate member--has also been created and the organizing of the secretariat, following its recent relinquishment by the Food and Agriculture Organization, has been entrusted to the president himself.

The Union accepted an invitation from Germany to hold the next Congress there. After the Congress at Vienna, about 130 of the delegates took part in strenuous study-tours that lasted for 11 days of magnificent weather and covered the whole country. One tour concentrated on silviculture and management, another on the many aspects of forest protection, and the third on mechanical developments in soil-cultivation and trenching, tree planting and tending, timber extraction and milling.

F. C. FORD-ROBERTSON

\title{
NUTRITION AND POULTRY
}

T HE Scottish Group of the Nutrition Society held its sixty-second meeting on September 30 in the College of Agriculture, University of Edinburgh. It took the form of a symposium entitled "Nutrition and Poultry". As the chairman, Prof. S. J. Watson (University of Edinburgh), pointed out in his opening remarks, since the subject was "Nutrition and Poultry" it was not confined to problems of poultry feeding but instead embraced broader aspects of nutrition in which work with poultry has contributed to knowledge.

Dr. W. P. Blount (British Oil and Cako Mills, Ltd., London) opened the proceedings with a very thorough exposition of the use of birds as experimental animals. Ho said that apart from some cage birds which have special uses, poultry were the most commonly choson birds for laboratory work, and he emphasized the advantages of their cheapness, availability and ease of management. Illustrating his talk with a series of informative slides, ho de. scribed different forms of housing, from brooders for small groups of chicks to intensive houses for many thousands of adult birds. He discussed optimal conditions of light, temperature and humidity, systems of feeding and ingredients of poultry diets. He concluded with a survey of the common diseases of poultry, and indicated that many of them could be controlled by good management and the judicious use of drugs such as antibiotics and coccidiostats.

In the following paper Dr. M. E. Coates (National Institute for Research in Dairying, Shinfield) dealt with problems of fundamental nutrition for which poultry have proved peculiarly suitable subjects, particularly in vitamin research. The examples quoted ranged from Eijkman's classic observation of polyneuritis in hens fed on polished rice, which led to the discovery of vitamin $\mathrm{B}_{1}$, to modern work on the isolation and function of vitamin $B_{12}$, a field in which work with poultry has played a major part. The developing chick embryo was cited as a very suitable organism for investigating the biochemical role of nutrients, as evidenced by experiments on the metabolism of vitamin $B_{12}$ and studies in tissue culture of the function of vitamin $A$. She described how chicks can be relatively easily maintained in a germ-free state and are thus becoming increasingly important in investigations of the relation of the alimentary microflora to nutrition.

Prof. S. Lepkovsky (University of California), who has used birds to study the nervous control of food intake, gave a fascinating dissertation on hunger, appetite and satiety. He described the influence of the central nervous system through hunger- and satioty-centres in the hypothalamus. He illustrated the psychological effects of these states amusingly and accurately in a series of lantern slides of "Hubert", an unfortunate character from a comic cartoon who was obliged to subsist on a low-calorie diet.

It has become common practice to include in diets for livestock non-nutritional additives that increase growth-rate and level of production. In reviewing additives for poultry diets Dr. J. H. Taylor, 
(Cyanamid Products, Ltd., London) classified them into those that alter the microbial flora to the benefit of the host animal and those, largely having hormonal activity, that produce increases in growth or productivity by modification of metabolic processes. The former class of compounds was of greater practical importance, and had the largest effect when the level of performance was poor. Detectable quantities of some antibioties given in the diet appeared in the serum. If there was reason to suppose that the beneficial effect of the antibiotic was systemic it was desirable that blood-levels should be increased. If, however, the response to an antibiotic was solely due to modification of the gut flora, such enhancement was unnecessary. The hormonal food additives such as cestrogens and thyroid-active agents could be of use in increasing fat deposition and improving carcass quality, although there was some danger of residues in the tissues if oestrogens were given in the food.

The final paper in the symposium was an enter. taining account by Prof. M. F. M. Meiklejohn (University of Glasgow), speaking in his capacity as editor of Scottish Birds, of wild birds that have been used as food for man. He began by reading from the Book of Leviticus the catalogue of birds that were prohibited as food by Mosaic law, and showed how nearly it corresponded to the list of birds customarily considered as unfit for consumption. The choice of wild birds for human food depended on their palata. bility and the ease with which they could be captured. In general, sea birds were less palatable than land birds, although there were instances of inhabitants of remote islands subsisting on some of the colonial nesting species. Of the land birds, those that lived in flocks and hence were more easily caught in quantity were most frequently a source of human food. Many of the traps and nets used to-day by ornithologists derived from the catching devices evolved long ago for the capture of wild birds for food. Prof. Meikle. john posed a number of questions, which the audience attempted to answer, about the relation between the food of wild birds and their suitability for human consumption.

The lively discussion that followed each of the papers fully justified the choice of subject for this symposium. On this occasion at least, the more homely aspects of the domestic bird were overshadowed by its role in the field of nutritional science. M. E. Contes

\section{THE EUROPEAN NUCLEAR ENERGY AGENCY}

\begin{abstract}
7 THE third report of the European Nuclear Energy Agency *, presented to the Consultative Assembly of the Council of Europe by Prof. S. Balke on September 26, records substantial progress in the first joint undertakings. Work on the Eurochemic site was inaugurated in July 1960 and the detailed preproject for the plant was approved in June 1961 . The Halden heavy-water reactor reached boiling in October 1960 with the first fuel charge of natural uranium, and installation of a second fuel charge of enriched uranium will permit a power of $20 \mathrm{MW}$. to be reached before the end of the year: joint operation of the reactor has been extended to the end of 1962 . Construction of the Dragon high-temperature gascooled reactor began in April 1960: civil engineering work on the site is well advanced and supporting research and development are progressing in parallel.
\end{abstract}

A group was set up in November 1960 to study the nuclear propulsion of ships, and a meeting of experts has been convened to determine the areas of nuclear research where particular need for international co-operation exists and the objectives and means of collaboration.

The European-American Nuclear Data Committee, created in June 1959, reviews the measurement programmes of member countries, inventories the equipment available, and has compiled a list of requests for new measurements so as to facilitate collection of the necessary data. It is also assisting countries which have only recently begun to work in this field, and the Agency, in July 1961, decided to establish a European system of supervision and emergeney warning which involves the immediate notification of any abnormal increase in environmental radioactivity recorded in a member country. A study-group on food irradiation was set up in

* Organtzation for European Economic Co-operation-Furopean Nuclear Energy Agency. Third Report on the Activities of the Agency European Nuclear Energy Agency, 1961.)
January 1960 to examine the economic and technical possibilities of the application of food irradiation so as to harmonize national programmes and propose joint projects where appropriate. International seminars for university teachers and technical executives were again organized in 1960 and 1961 , and a specialized symposium on criticality control in nuclear industry at Karlsruhe was attended by one hundred specialists.

The Agency has also undertaken the examination of regulatory, administrative and legislative provisions introduced by European countries to conform with the radiation protection norms adopted in 1959 , and these norms are being revised, in liaison with Euratom and the International Atomic Energy Agency, to take account of the latest recommendations of the International Commission on Radiological Protection. A Convention on Third Party Liability in the Field of Nuclear Energy, dated July 29, 1960, has been signed by sixteen members of the Organization for European Economic Co-operation. The Agency also participates in the investigation of problems posed by the insurance of nuclear risks. and particularly the application of tax regulations governing technical reserves and insurance premiums to these risks. A first set of regulations applicable to research or experimental reactors has been elaborated. by the Control Bureau responsible, under the Agency's Steering Committee, for carrying out the Security Control Convention. In addition, the Agency centralizes economic data bearing on the development of the nuclear industry, and the result of an investigation, published in 1960, predicted that nuclear power stations will provide less than 3 per cent of the capacity of the European electricity production in the coming five years and less than 10 per cent in fifteen years.

The practical value of international co-operation in this field is fully established by the year's work, and the experience gained in co-ordinating scientific work 